Images in...

\title{
Severe type IV hypersensitivity to 'black henna' tattoo
}

\author{
Vasileios Vasilakis, ${ }^{1}$ Bernice Knight, ${ }^{2}$ Satnam Lidder, ${ }^{3}$ Sarah Frankton ${ }^{4}$ \\ 1 Department of Acute Medicine, St Bartholomew's and The Royal London Hospitals, London, UK \\ ${ }^{2}$ Department of Acute Medicine, The Royal London Hospital, London, UK \\ ${ }^{3}$ Department of Clinical Pharmacology and General (Internal) Medicine, St Bartholomew's and The Royal London Hospitals, London, UK \\ ${ }^{4}$ Departments of Acute Medicine, Endocrinology and Diabetes, The Royal London Hospital, London, UK
}

Correspondence to Sarah Frankton, sarah.frankton@bartsandthelondon.nhs.uk

\section{Summary}

A 16-year-old Bangladeshi girl presented with a 9-day history of an extensive pruritic, erythematous, papulovesicular skin eruption to both forearms. Appearance was 5 days following application of a home-made henna preparation. Examination revealed ulceration and scabbing along the whole henna pattern and early keloid formation. A diagnosis of type IV delayed hypersensitivity reaction superimposed by infection was initially made. As in this case, home-made henna preparations commonly combine commercial henna with black hair dye, paraphenylenediamine (PPD). PPD, widely known as 'black henna', darkens the pigment and precipitates the drying process. PPD is a potent contact allergen associated with a high incidence of hypersensitivity reactions. Despite treatment the patient was left with extensive keloid scarring in the pattern of the henna tattoo.

\section{BACKGROUND}

The case highlights the potential dangers of using henna skin dyes containing contact allergens in hypersensitive individuals. The scarring may be extensive and will be permanent and usually in an exposed area. There is little that can be done to minimise appearances. Since this is a common practice in many cultures we felt there was an imporotant public health message to be highlighted from this case and in addition, the appearances of this young girl's forearms produced some very striking pictures.

\section{CASE PRESENTATION}

A 16-year-old Bangladeshi girl presented with a 9-day history of an extensive pruritic, erythematous, papulovesicular skin eruption to both forearms. Appearance was 5 days following application of a home-made henna preparation.

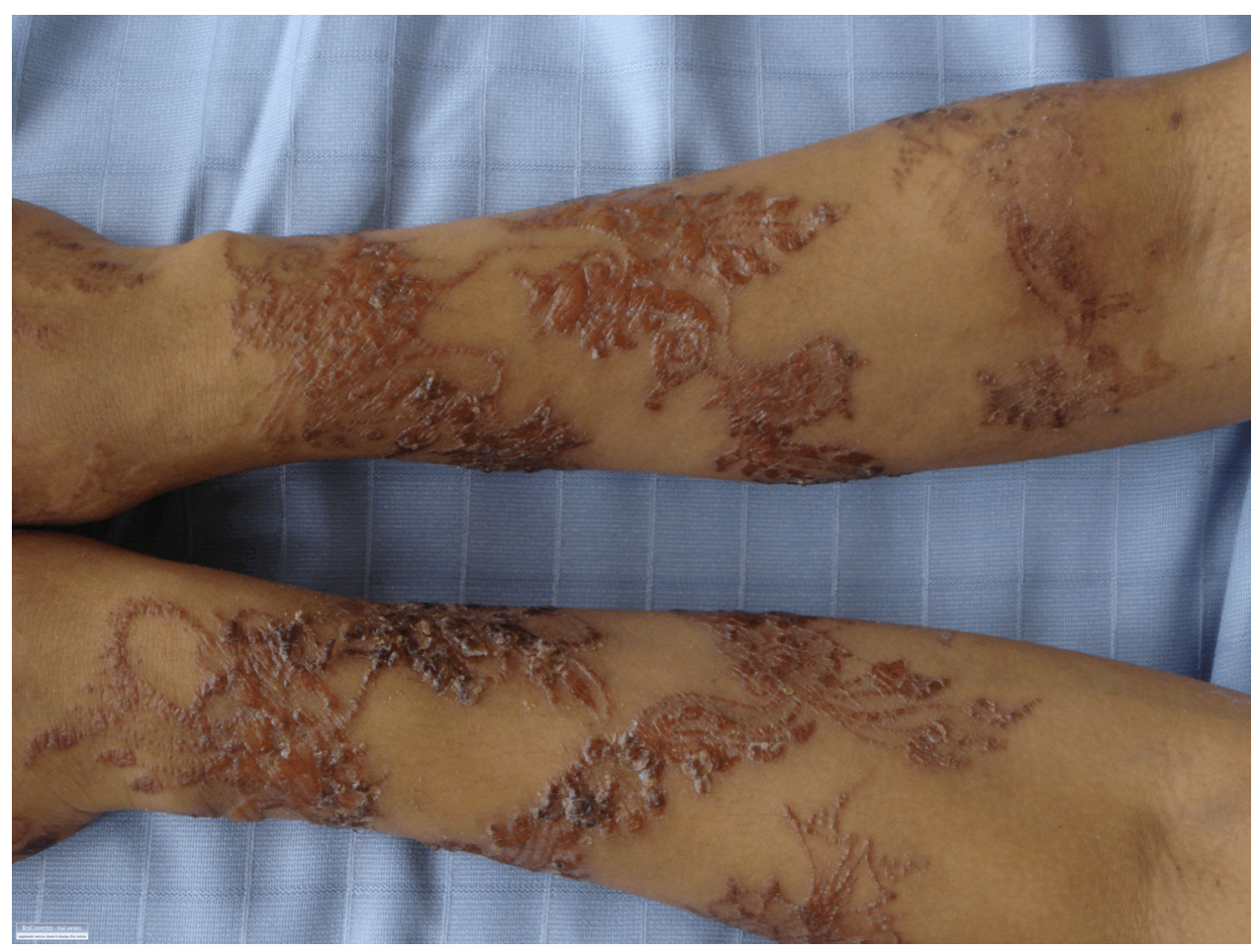

Figure 1 The patient's skin eruption 2 days following treatment with intravenous antibiotics and oral steroids. The papulovesicuar rush and erythema have settled. $1083 \times 812 \mathrm{~mm}(72 \times 72 \mathrm{DPI})$. 


\section{BMJ Case Reports}

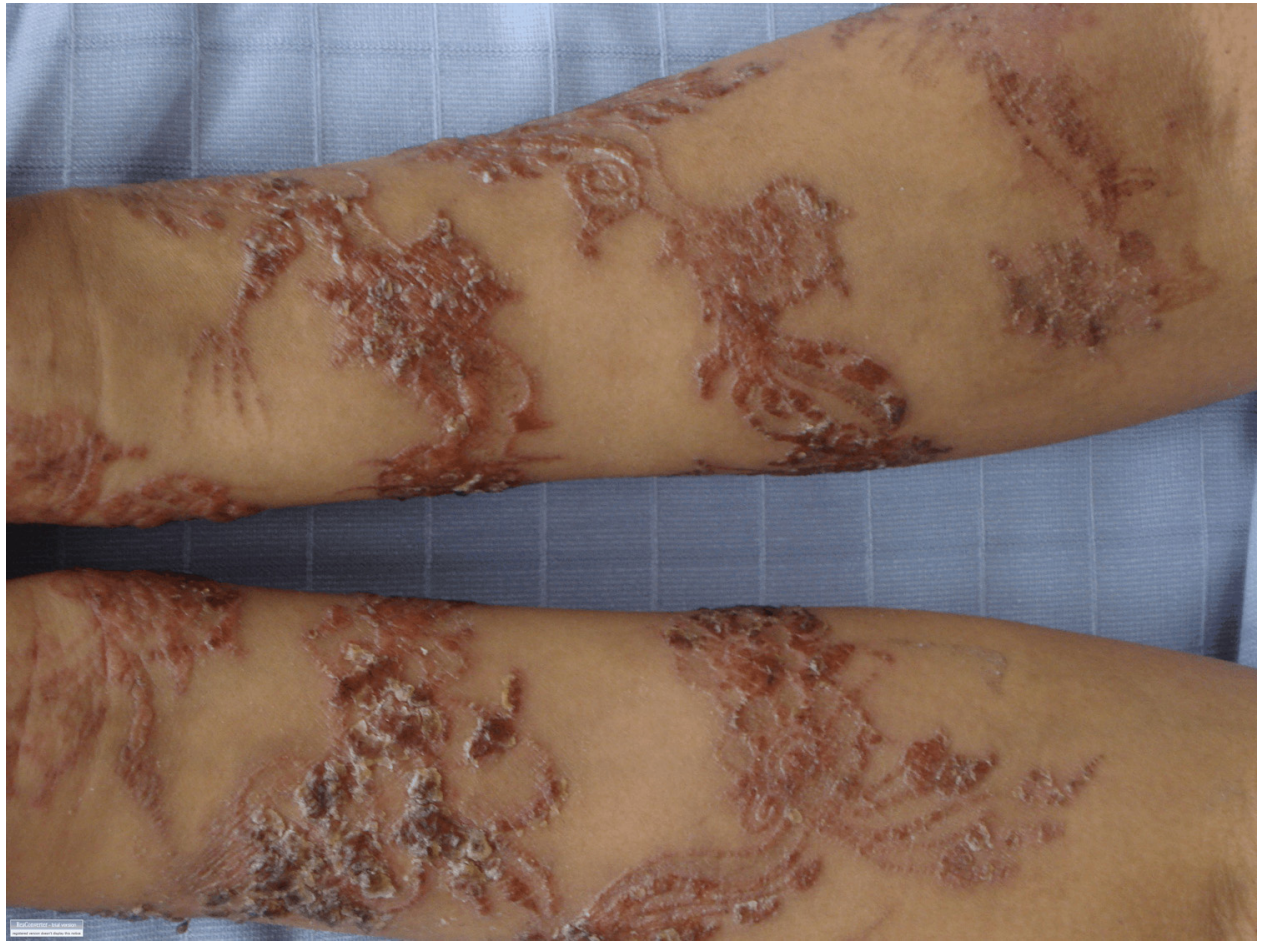

Three previous applications of commercial henna were uneventful but she had past history of allergic dermatitis to silver. Examination revealed ulceration and scabbing along the whole henna pattern and early keloid formation. A diagnosis of type IV delayed hypersensitivity reaction superimposed by infection was initially made and intravenous flucloxacillin and benzylpenicillin given as a precautionary measure. Subsequently, the $\mathrm{C}$ reactive protein (CRP) was $<5$, and there was no leucocytosis, suggesting the fever (38.7C) was secondary to the hypersensitivity reaction. She was treated with systemic and topical corticosteroids, antibiotics and an antiseptic lotion (figure 1). Repeated superficial corticosteroid injections would be required to minimise keloid scarring (figure 2).

As in this case, home-made henna preparations commonly combine commercial henna with black hair dye, PPD. PPD, widely known as 'black henna', darkens the pigment and precipitates the drying process. PPD is a potent contact allergen associated with a high incidence of hypersensitivity reactions. Patients with contact dermatitis are at higher risk of severe reactions. ${ }^{1}$ The extent of reaction depends on the concentration and duration of exposure to $\mathrm{PPD}^{12}$ and can lead to keloid formation. The treatment of this is often challenging, with high reoccurrence despite therapy. ${ }^{3}$ Subsequent allergic sequelae with PPD sensitisation are frequently observed. This is important since PPD and PPD like substances are found in many products used in daily life. Public health messages of the risks of 'black henna' should be emphasised in communities of high traditional significance, particularly to those with underlying chemical allergies.

\section{INVESTIGATIONS}

Full blood count, blood cultures, CRP are the relevant investigations.

\section{TREATMENT}

Intravenous then oral flucloxacillin and benzylpenicillin, oral prednisolone, Dermol 500 topically, an antiseptic lotion.

\section{OUTCOME AND FOLLOW-UP}

Extensive keloid scarring in the pattern of the henna tattoo was present at follow-up. The patient was seen in the plastic surgery clinic for follow-up where local corticosteroid injections were being considered as possible therapy.

\section{DISCUSSION}

Gregory Sonnen from The Baylor University Medical Center reported a Type IV hypersensitivity reaction to a temporary black henna tattoo in a 6-year-old boy in 2007. Jacob Urkin wrote an article "Henna tattooing dermatitis: consider an additive as the culprit" in the British Journal of General Practice in 2006 and Wolf et al, wrote about cutenous reactions to temporary tattoos in the Online Dermatology Journal in 2003. The latter two articles were reviews rather than case reports. 


\section{BMJ Case Reports}

\section{Learning points}

- PPD widely known as 'black henna', is a potent contact allergen associated with a high incidence of hypersensitivity reactions.

- The public should be made aware of potential hypersensitivity reactions which may result in permanent scarring.

- Retailers and manufacturers should advise customers to perform a skin patch test before using these products.
Competing interests None.

Patient consent Obtained.

\section{REFERENCES}

1. Sonnen G. Type IV hypersensitivity reaction to a temporary tattoo. Proc (Bayl Univ Med Cent) 2007;20:36-8.

2. Gawkrodger DJ, English JS. How safe is patch testing to PPD? $\mathrm{Br} J$ Dermatol 2006;154:1025-7.

3. Juckett G, Hartman-Adams H. Management of keloids and hypertrophic scars. Am Fam Physician 2009;80:253-60.

This pdf has been created automatically from the final edited text and images.

Copyright 2010 BMJ Publishing Group. All rights reserved. For permission to reuse any of this content visit

http://group.bmj.com/group/rights-licensing/permissions.

BMJ Case Report Fellows may re-use this article for personal use and teaching without any further permission.

Please cite this article as follows (you will need to access the article online to obtain the date of publication).

Vasilakis V, Knight B, Lidder S, Frankton S. Severe type IV hypersensitivity to 'black henna' tattoo. BMJ Case Reports 2010;10.1136/bcr.09.2009.2277, date of publication

Become a Fellow of BMJ Case Reports today and you can:

- Submit as many cases as you like

- Enjoy fast sympathetic peer review and rapid publication of accepted articles

- Access all the published articles

- Re-use any of the published material for personal use and teaching without further permission

For information on Institutional Fellowships contact consortiasales@bmjgroup.com

Visit casereports.bmj.com for more articles like this and to become a Fellow 